\title{
Multiple Narratives of II/legality and Im/morality: The Case of Small-Scale Hashish Harvesting in Kyrgyzstan
}

\begin{abstract}
The aim of this study is to contribute to_the current literature concerning the social acceptance of illegal practices. Using legal pluralism as a general framework of analysis, this study discusses the relationship between state law and alternative perspectives concerning its legitimacy. It presents the experience of people involved in hashish harvesting in one of the regions of Kyrgyzstan, how the state defines it as an "illegal practice", and how the local population subsequently invokes normative systems based on local spiritual knowledge and the local moral economy of hashish production. It argues that acceptance of hashish harvesting as a legitimate means of support is not a straightforward process. Despite the predominant legitimating narrative of hashish harvesting, it enters into a conversation with state defined notions of "illegality" and is also shaped by the customary understanding of the spiritual power of cannabis plants that requires caution when making hashish.
\end{abstract}

\section{Keywords}

Legal pluralism, legitimation of illegality, corrupt law enforcement, neutralization techniques, moral economy, customary law, illegal drug production 


\section{Introduction}

During the summers of 2008 and 2009, I stayed with a family in Toolu village ${ }^{1}$ in the Tyup region of Kyrgyzstan. This region was known for its wild-growing cannabis plants with a higher concentration of tetracannabino ${ }^{2}$ than elsewhere in the country. Hashish and marijuana ${ }^{3}$ made in Tyup had a wide-reaching reputation even during Soviet times, especially among members of the criminal underworld who came to the region during summertime to process the plants. However, hashish-making only became widespread among the local population following the dissolution of the Soviet Union when former kolkhoz and sovkhoz workers turned to illegal hashish and marijuana production alongside other economic activities. During the 2000s, hashish-making became an informal source of economic and social security among Kyrgyzstan's cannabis harvesters. Toolu inhabitants understood that hashish-making was an illegal enterprise but came to accept it as a means of income in the context of rapid impoverishment, weakened state welfare services, and a limited job market.

My research is based on a mixed method study undertaken in the Tyup and Ak-Suu raions ${ }^{5}$ located in the Karkyra valley of Issyk-Kul oblast ${ }^{6}$ in Kyrgyzstan. I collected sixty-four informal interviews and conducted a survey from 147 structured interviews. Fieldwork took place over nine months during which I visited the main research site, Toolu, on two separate occasions. The trips took place from July until December 2009 and from July until September 2010. While ethnographic research allowed me to learn about local residents' attitudes towards the illegal drug economy, which would have been impossible through a more formalised and structured approach, the survey allowed me to obtain general information on the socio-economic conditions of Toolu households.

Using the example of illegal hashish harvesting in Toolu, this paper explores the everyday responses to illegality and perceived im/morality. Many studies of the post-Soviet region argue

\footnotetext{
1 The name of the village has been changed for ethical reasons.

2 Tetracannabinol is the main psychoactive ingredient of cannabis plants.

${ }^{3}$ Hashish is a cannabis resin and marijuana constitute of cannabis leaves.

${ }^{4}$ Kolkhoz was a collective farm and sovkhoz was a state collective farm. In rural agricultural areas such collective farms employed most of the population during Soviet times.

${ }^{5} \mathrm{~A}$ raion is a smaller administrative region within an oblast.

${ }^{6}$ An oblast is a type of administrarive region, similar to a county in the UK.
} 
that state authorities were themselves involved in illegal activities as a result of the infiltration by criminal groups or the predatory tendencies of the state itself (Beck and Chistyakova, 2002; Gans-Morse, 2012; Kupatadze, 2014; Stephenson, 2015). They remind us of the ambivalent nature of the state, where illegality does not necessarily threaten it and in some cases the state uses illegal practices to strengthen its position (Reeves, 2014).

More recently, the local community standpoint has emerged as a defining feature in studies of illegality. Alternative viewpoints towards what was defined as il/legal allow us to understand the multifaceted morality of illegal transactions (Humphrey, 2002), acceptance of informal practices (Ledeneva, 2006), and the discrepancies between local, cultural and state understandings of bribery (Polese, 2008; Werner, 2000). This literature demonstrates that some activities defined as illegal by the state could be defined as appropriate and ethical according to the "living law" guiding quotidian perceptions and moral codes (Urinboyev and Svensson, 2013).

Many studies outside the post-Soviet region demonstrate how illegal practices, despite pressure from states and social institutions, become legitimated locally (Galemba, 2012; Galemba, 2013; Webb et al, 2009; Westermeyer, 2004). For De Sardan (1999), some cases highlight the local context and specific conditions that enable a practice which is grounded in native cultural norms and legal regulations and contrasts with Western criminal justice and definitions of corruption. Galemba's (2013) work illuminates how the contraband sale of corn from Mexico to Guatemala was legitimated by the everyday working practices of poor people who were trapped by neoliberal market conditions. Engwicht (2017) also found that illegal mining and the sale of diamonds in Sierra Leone were considered as moral by local miners. In Dewey's (2012) research, illegal practices of car thefts and their trading in Buenos Aires was legitimated, or at least tolerated, due to the protection provided by the police.

While providing good explanation for the existence of legitimating narratives for violation of legal rules, these studies have mostly focused on informal economic activities exchanging or producing otherwise legal goods. While according to Beckert and Wehinger (2012) illegal economic activities also include violation of legal regulations while exchanging or producing illegal goods. Legitimation of activities involving illegal goods much more difficult compared to 'informal' ones, and varies depending on people's perception of such goods (Ibid, 2012). Thus, more studies focusing on legitimating narratives of 'illegal' activities that do not 
only violate the legal rules but also involve illegal goods are needed. This paper, aims to contribute to this literature, as hashish itself and its production and sale are illegal in Kyrgyzstan.

In this paper, I argue that the persistence of illegal hashish harvesting in Toolu should be understood in relation to a wider legitimating narrative, which refers to work ethics and moral judgements about the corrupt behaviour of state officials. This wider narrative is further complicated by local understandings of the spiritual power of cannabis plants. I will begin by reviewing the literature concerning the co-existence of local and state responses to hashishmaking. This will be followed by a description of the hashish-making process and the main actors in Toolu. I then turn my attention to the process of legitimation used by the local population, by first discussing the right to subsistence and work, and how cases of corruption among law enforcement officers lead to changes in the perception of the law and the role of the state. With these dynamics in play, some residents still denied that hashish-making was part of their strategy to overcome the psychological tensions between the legal rules and the harsh reality of rural life in a neoliberal state. The last section presents how money earned through hashish is also seen as "bitter money".

\section{Plurality of il/legality and im/morality}

To explain how an activity that is illegal in the eyes of the state, and had been popularly considered to bring bad luck, became an acceptable practice at a certain juncture, I will draw on concepts from otherwise disconnected fields of study.

First, I focus on the notion of "moral economy" initially coined by E.P. Thompson (1971) when writing about the bread riots in 16th and $17^{\text {th }}$ centuries in England. This concept is widely used in studies focusing on the legitimation of certain extra-legal activities (De Sardan, 1999, Engwicht, 2017; Steinberg et al 2004) as it explains how people may resist state-defined notions of illegality. Scott (1985) analysed riots in East Asia during the mid-20th century through the prism of the moral economy. Riots occurred not because people were inherently deviant, but because of how they perceived justice as a result of the state/elite no longer following the rules that once governed relationships. Betrayal by the state, or common perceptions of feeling betrayed, are key here as they justify "deviant" and "illegal" behaviours in the context of the changing dynamic between state (elite) and population and the shift in law/regulations. Other 
studies apply this concept in their analyses of persistent corruption (De Sardan, 1999) and illegal drug production (Steinberg et al 2004) in countries where laws changed in the wake of European/western domination and associated neglect of local traditions, culture and legal regulations. The legitimation of acts of resistance in the production of coca, opium and cannabis was therefore rooted in indigenous rights and culture (Ibid 2004).

However, the legitimation of illegality is not simply a linear process. The complexity of different responses is also seen in the rejection of social and cultural understandings of extralegal activities as legitimate, confirming the state's view of illegality. In criminological research, some authors adopt "neutralization techniques" as a lens through which to explain why people, who generally conform to societal norms, engage in deviant and criminal behaviour. "Neutralization" refers to the psychological technique of balancing and adjusting to cognitive dissonance (Matza, 1964; Sykes \& Matza 1957). Here we see how violation of the law can create feelings of guilt among delinquents, who have not completely disassociated themselves from the legal forms of sociability. Although they are knowingly involved in illegal activities, the psychological strategies of neutralization help them deny various aspects of illegality.

More recent studies have explored the concepts of "neutralization" and "moral economy" more deeply. For instance, in their study of the acceptance of illegal behaviour among orchid and antiquities collectors, Mackenzie and Yates (2015) argued that the "moral economy" concept could be incorporated into a criminological approach towards "neutralization". The moral economy can be seen as an appeal to higher loyalties and as a "master narrative" among collectors of rare orchids and antiquities, which is supported by other subsidiary techniques of neutralization that promote the image of this type of collecting as a "good thing".

While agreeing that neutralisation techniques can create the grounds for legitimating illegal activities, I argue that the concepts of neutralization and moral economy should be kept separate, as communities involved in illegal practices can develop different responses towards illegality ranging from denial to legitimation. The moral economy is based on the idea of justice and a sense of having the right to break certain laws. This implies a questioning of the moral claims of the state itself and often makes laws unfit for contemporary social needs. This kind of neutralization focuses on the cognitive dissonance that illegality creates and the psychological defence mechanisms of either complete denial or justification. While both concepts are useful, 
their central premise still views legality and illegality as mutually exclusive and clearly juxtaposed; thus falling short of explaining conditions and contexts where boundaries may be blurred.

Illegality can be tolerated by the state itself, signalling that such practices can continue in spite of formal law. Hence, the roots of the de-legitimation of power should also be sought within the system itself. Put simply, by deviating from its own rules and governing practices, the state undermines its own legitimacy. Recent studies in the post-Soviet region argue that this is related to the selective enforcement of laws (Brooke and Gans-Morse, 2016), and the way the criminal justice system operates and interacts with people (Hendley, 2015) Likewise, in their study of attitudes towards law in post-Soviet Georgia, Slade and Kupatadze (2017) argue that procedural injustice encountered by individuals in their interactions with criminal justice representatives have led to a low level of legitimacy of the law and state. In their study of public health programmes implemented in Russia, Brooke and Gans-Morse (2016) argue that individuals reacted to the ways in which laws were actually implemented, noting whether the state itself sent signals that a particular law was going to be enforced, or whether it would be a mere formality. Moreover, state representatives' actions might lead to blurring the lines between legal and illegal activity (Heyman 1999; Reeves, 2014), further legitimating illegality among the population.

Whilst providing grounds for our analysis of the legitimation of illegality, these theories still lack a component that would enable us to explain both concepts of value and perceptions of income made illegally. Here I propose to build on terms developed in anthropological work on money, especially the concepts of "tainted", "polluted" or "bitter" money (High, 2013; Shipton 1989). These concepts allow us to better analyze the perception of hashish harvesting as connected with potential misfortune. Such studies focusing on "bitter" (Shipton, 1989) or "polluted" money (High, 2016) point to how local, religious understandings can identify some activities as dangerous, not only in the physical and legal sense, but also symbolically and spiritually. Despite the implicit moral tensions, these studies illustrate how rituals are used in the cleansing of money (Shipton, 1989, High, 2017) and how the purchase of durable goods with "polluted" money is avoided since it may alter the destiny of an owner (High, 2017).

In order to analyse these different responses to legality and illegality, morality and immorality, I turn to theories of legal pluralism developed within legal philosophy (MacCormick, 2007), sociology and anthropology of law (Tamanaha, 2001; Nujiten and Anders, 2007). 
According to legal pluralism, state law is not the only normative system that rules the lives of people and alternative, sometimes conflicting, modes of normative systems can co-exist (MacCormick, 2007). This helps to explain the phenomenon of persistent illegality among a population that does not perceive itself as criminal. Although state law was seen and studied as the major authoritative and legitimate source of codes of behaviour within nation-states, more recent studies have pointed to the existence of legal plurality, recognising the fact that contradictory laws can co-exist (Tamanaha, 2001). In such cases, customary, religious or indigenous laws, or "living laws" (Urinboyev and Svensson, 2013) can co-exist within an institutional normative system (MacCormick, 2007). The "mirror thesis" proposed by Tamanaha (2001) suggests that state law might not necessarily mirror a society's morality and customs. This general thesis lets us assume that different types of responses are possible in this process of shifting from a high- to low-level mirroring of the local normative system against the state law. Thus, while the predominant narrative remains the legitimation of illegality, other responses that account for cognitive dissonance while breaking the law, and/or perceiving their acts as immoral in making "tainted" or "bitter" money are possible. This could lead, though, to difficulties in unravelling formal and informal, legal and illegal, moral and immoral since they become intertwined, interdependent and entangled (Heyman and Smart, 1999: 11). Consequently, while acknowledging legal pluralism as a general framework for explaining the existence of various normative systems, we also need to remember that at certain points in the shift from a high to low level "mirroring" (Tamanaha, 2001), demarcating clearly the boundaries between law and other local normative systems becomes difficult due to the creation of "grey areas" (Heyman, 1999).

\section{Hashish Harvesting}

Unlike other drug supplying countries such as Morocco, hashish-makers in Toolu were unable to produce drugs on a large scale (Decorte et al., 2011; Kurtz-Phelan, 2005). Since they harvested wild cannabis, hashish-makers needed to constantly move from one field to another to find plants with intact upper leaves suitable for rubbing. Once in a good location, hashish-makers would busy themselves rubbing the leaves and seeds of plants between their palms.

The most visible group in Toolu consisted of young adults in their twenties and thirties. They were mostly males, who travelled by horse to the mountains to collect the hashish. In the 
early morning, small groups of two or three men would leave for the hills. Women made hashish either within the village boundaries on small patches of uncultivated land or on the nearby hills. In some cases, small peer groups of sixteen to seventeen year olds went alone to the fields. A few twelve to thirteen year olds also learned how to make hashish by joining their parents. Most of the hashish-makers described themselves as "everybody else" (typical) or poor and were usually facing extreme economic hardship. Like farmers in other post-Soviet agricultural regions, who experienced much higher levels of poverty than urban dwellers (Mandel and Humphrey, 2002), Toolu's residents struggled to secure cash throughout the year due to market fluctuations, a lack of credit in rural regions, and harsh weather conditions affecting harvests.

None of the hashish-makers were paid up-front by dealers or drug lords for harvesting the cannabis resin, as it happened in other countries (Ahmadzai and Kuonqui, 2011). Occasionally, some traders of clothes and household goods would accept hashish as payment. In such transactions, traders used an established price of one matchbox (usually lower than the price of a matchbox sold directly to dealers) and recalculated the price of a given commodity so that customers would know how many boxes of hashish they would need to bring to settle "credit". As sellers mainly used this informal crediting system in winter or spring when most struggled for cash, some agreed to barter on these terms and would need to make hashish in summer/early autumn to return it.

Locals serving as middlemen or women drive the local hashish economy. The middleperson's job is to connect local drug makers with dealers, usually from outside the region. Typically, dealers were not complete strangers to producers or middlepersons and were either former villagers, who had moved to other regions or friends/relatives of villagers with good connections. The hashish-makers usually preferred to sell in the vicinity of the village and not be involved in transporting the drug to other regions. Nurgul, a woman in her mid-30s, sometimes took the risk of working as a middleperson. She explained that she had her own contacts among women who made kara-kuurai [hashish]. When there was a dealer, who wanted a certain quantity, she just needed to spread the word among friends that they can bring the hashish to her house. Working as a middleperson was more profitable and farmers could earn cash faster than making hashish by hand. However, due to the higher risks of being caught by law enforcement officers during the sales, few villagers were prepared to take on this role. Nevertheless, there were some ten families in the village involved in this risky business. Some only worked as middlepersons 
after obtaining "protection" from police officers to whom they were expected to pay around tenthousand som $\left(£_{1} 142\right)$ per month. In order to offset the expenses of bribing police and to turn a profit they needed to provide their services for dealers more frequently. As my interviews reveal, middlepersons were relatively well-off and did not make hashish themselves. Issues relating to the police "protection" of middlepersons and associated bribes are discussed in the following sections where I develop an analysis of the development of different responses to hashishmaking among the local population.

\section{From Theory to Empirical Evidence: Multiple Narratives of Il/legality and Im/morality}

After collecting data during nine months of ethnographic fieldwork I had numerous notes and interview transcripts pointing to the complexities underpinning how hashish-making was perceived among the villagers of Toolu. These varied from those who rejected it as a way of life, to those who saw it as a legitimate means of money-making, albeit with some caution. The latter's view had become the dominant narrative over the last three decades. In what follows, I analyse the case of hashish production and it's legitimation. This helps us extend the boundaries of the theoretical framework for understanding the legitimation of illegal practices.

\section{Moral economy of hashish making}

Although cannabis was harvested in the territories of Issyk-Kul region during Soviet times, with a few exceptions when young local residents were caught making cannabis for their own consumption (Korchagina, 1987), different groups of non-residents of the region, and from wider afield, were reported as responsible for collecting and transporting the drugs throughout the 1980s. This situation changed in the mid-1990s when almost all local residents, young and old, began to collect cannabis resin. They did not suddenly start using hashish but rather produced it for sale. The involvement of large numbers of people in hashish-making since the 1990s, usually unassociated with criminal underground groups, thus required some legitimation.

At the beginning of the 1990s it was far easier to develop an alternative morality to justify involvement in illegal production. Many, when relating how they started making hashish then, 
referred to surviving the impoverishing economic conditions following the breakdown of the Soviet Union. Such drastic transformations resulting in the state's withdrawal from social welfare and planned economy represented a betrayal of ordinary people. People still referred to their right to work, once provided by the state, and a right to subsistence that was highly dependent upon state support. However, with independence, the economic reforms that started during the late 1980s took a neoliberal turn and many were left without jobs since kolkhoz and sovkhoz assets were privatized and land distributed among the rural population.

Many, except those from the wealthiest families, referred to the beginning of the 1990s as years of extreme hardship.? Kalys, for example, remembered that "[t]he most difficult years were when we separated from the sovkho\%. We did not have seeds. The government distributed twenty-six kilograms of wheat seeds for one hectare of land, while it needs two-hundred and fifty kilograms". Later, such feelings of betrayal intensified under the new neoliberal policies where the agricultural sector received no state protection. Consequently, prices were subject to market regulation alone, resulting in prices for agricultural products remaining constantly low, unpredictable and fluctuating from year to year. The general perception was that the government should be more proactive and provide protection from the "free-market" instead of leaving agricultural production to its own devices.

In light of government failure to initiate new employment opportunities, claims that drug production was illegal became questionable in the eyes of ordinary people surviving on a range of precarious incomes. ${ }^{8}$ Instead, people referred to hashish-making as a form of subsistence during times of hardship. Almost everyone I talked to justified hashish production by referring to the absence of jobs in the village; the fact that people had to earn money with few options available and, significantly, the perceived state responsibility to guarantee jobs. Hashish-making is referred to here as their work, which is relatively common among drug producing communities across non-western societies (Calderón, 2016). The claim that it is not an illegal activity supplementing work but a form of work in itself was used in many other situations and contexts in post-Soviet countries (Humphrey, 2002: 119).

\footnotetext{
${ }^{7}$ Rrural regions, specifically, experienced increased poverty in other post-Soviet countries during the 1990s (Mandel and Humphrey, 2002: 9).

8 People from many post-Soviet countries were surviving in any way they could. In Russia, during the 1990s, supplementing low salaries with covert earnings was widespread (Birdsall, 2000).
} 
I frequently heard Jamilya, a woman in her mid-30s, and her friends saying to each other "let's go to work" or asking "when will we work?" when talking about hashish-making. This acceptance as work suggests a form of a moral economy as people invoke the moral principles of justice in terms of their right to subsistence (Engwicht, 2016; Thomspon, 1991; Scott, 1985). The language of independently working and not seeking money or assistance from anyone is a powerful mechanism for legitimating illegal practices.

\section{Corrupt law-enforcement}

The legitimation of illegality becomes stronger when state representatives themselves fail to comply with state regulations (Beetham, 2001; Mathiesen, 1965; Slade and Kupatadze, 2017; Tyler, 2004). Corruption and informal protection of drug producers and traffickers by lawenforcement officers are the main reasons why drug markets flourish in many countries (Watt and Zepeda, 2012; Westermeyer, 2004: 128). On the one hand, it is their involvement in supporting the production and trafficking of illegal drugs that allows illegal drug economies to exist and persist globally. On the other, by accepting bribes or providing protection to producers and traffickers, corrupt law enforcement representatives allow illegal drug market actors to question law enforcement, the rule of law, and the state's quest for drug prohibition. Cases of corruption create an atmosphere where people feel injustice when judged as criminal while others, especially those in power, violate the law (Ruggiero and South, 1995). Police involvement in illegal activities in other western countries also reveals an increase in law breaking among the general population (Tyler, 2004).

The narrative of official involvement in extra-legal activity leading to a decline in state legitimacy accords with the theoretical approach to the legitimation of power (Beetham, 1991). Although, some high-level state authorities were either directly involved in the trafficking of heroin from Afghanistan and/or provided protection for easy transportation of drugs within and outside of the country (Kupatadze, 2014), locals did not discuss this aspect of elite corruption. Locals mostly referred to the low-level corruption of law enforcement representatives involved in the control of hashish production in the Issyk-Kul region, ${ }^{9}$ as drug-makers were constantly at

\footnotetext{
9 In many more profitable drug markets, such as opium/heroin and coca, state elites not only provide 'protection rackets' but also oversee the business on higher levels as was the case in Mexico (Watt and Zepeda, 2012) and
} 
risk of capture throughout summer and early autumn. On a local level, the provision of police protection (krysha), as well as bribes taken in exchange for non-arrest and opening of criminal proceedings, were frequently discussed.

Kalycha eje, a woman in her fifties, was cynical about police actions, believing that they did not only take bribes but also sold confiscated drugs instead of destroying them. The role of the police, in her understanding, involved earning money (illegally) rather than upholding the law. Kalycha eje raised important issues in relation to police corruption. First, she pointed out that law enforcement is itself compromised when catching hashish-makers. In her understanding, shared by many in the village, the police are making money off hashish-makers first, by charging bribes for release, and then by selling on confiscated hashish. Such practices of "performing" the law suggest that local officers have lowered the legitimacy of the police and of the law in general rather than demarcating the line between legality and illegality ${ }^{10}$ (Heyman, 1999) and (Dewey, 2012; Slade and Kupatdze, 2017).

Police officers usually arrested hashish-makers returning from the fields and mountains to their homes, since they were easy targets when carrying hashish. Their strategy was to arrive in unmarked cars and civilian clothes so that people would not be able to identify them as police from afar. However, these strategies contributed to a questioning and loss of legitimacy among the people (Beetham, 1991; Slade and Kupatdze, 2017). In the summer of 2006, a few local hashish-makers refused to be "arrested" by police officers. While police officers later explained the incident in interviews as disobedience to state representatives, locals described their actions as legitimate because in their perception police officers in plain clothes with no documents meant that they were trying to make false arrests and extort money.

Those stopped and found with hashish typically attempted to negotiate bribes with the police. Often they were successful and told how much money their relatives should bring in order to secure their release. If the relatives were able and willing to pay then the apprehended person would be freed within hours. Official papers filled out by officers would then be destroyed and the case no longer stood. The size of extorted bribes varied from five-hundred to

Tajikistan (De Danieli, 2011; Paoli et al., 2007). Even in Kyrgyzstan, the heroin market was associated with the involvement of high-level state representatives in the narco-business (Kupatadze, 2014).

10 Similar tendencies in how police officers pursue extra-legal 'money-making' activities are found in other postSoviet countries (Beck and Chistyakova, 2002; Gans-Morse, 2012; Levin and Satarov, 2000; Shelley, 1995) 
five-thousand som $\left(f 7\right.$ to $\left.f^{71}\right)$ depending on the amount of hashish found and their family connections with the police officers. The more drugs found, the more money demanded. Those, who only made hashish in the fields and were returning with relatively small amounts recently made, would be asked to pay less. In contrast, those who had a few korobochka's (matchboxes) of hashish with them for selling to dealers were asked for much more in order to be released with no charges. Those, caught with a number of matchboxes, were asked to pay up to twentythousand ( $£ 71-285)$. Those not paying protection fees, and having less money for bribes, or lacking connections with the police were most vulnerable to arrest by officers hoping to demonstrate their "effectiveness" through boosting arrest statistics.

Law-enforcement thus plays an essential role in blurring the boundaries between the legality and illegality of hashish harvesting since police can confiscate the drugs, transport them to the capital, sell for their own profit, and also provide protection to the middlepersons of the village for a fee. Consequently, the legitimacy of the law and of actors representing the state is eroded.

\section{Techniques of neutralization}

There were three main ways in which those not involved in hashish-making reacted to illegal hashish money. Some agreed that it helped families to survive economically, preventing families from starving or moving from the region in search of income. For those not involved in hashish production but who nonetheless supported it, it became easier to construct a sense of legitimation for the hashish producers' behaviour: they make hashish to earn money in order to feed their families, pay for education, medicine, livestock or participation in social gatherings through gift-giving. Others did not support hashish producers but still tolerated them, disagreeing with the practice yet not contacting the police or other authorities to provide information.

Lastly, representatives of the village's older generation (aksakals and apa) did not support hashish production and condemned it. As some participants highlighted, such people prefer to use literal denial strategies (Sykes and Matza, 1957) instead of openly discussing hashish production by their own children or grandchildren. Some young participants explained that although their parents and grandparents disliked them making it, they would not question where the money came from when used for support in financially difficult times. In this case, we see 
that the denial strategy was used not by the hashish producers themselves, but by close family members.

Neutralization strategies were also used extensively by hashish-makers. The process of distancing themselves from their product allowed them to dissociate from the negative connotations of drug use. For instance, most farmers making hashish did not inquire about where it went; they were uninterested in what happened to hashish beyond the production and sale stages taking place in the village. This lack of interest in what happens next does not mean that people knew nothing about its destination. Instead, it was a means of detaching their involvement in production from further consequences. It was easier to deny responsibility for the effects of hashish if they lacked knowledge of where it went or who used it. One producer, Kanat, said: "Where does it go? Probably to America or somewhere." Coca and opium growers in Afghanistan and Bolivia also deny any awareness of destinations and how the drugs were used (Kurtz-Phelan, 2005). Another respondent, Zuura, a woman in her 30s stated: "We hear about it. Sometimes, we see it on TV. Last year, I saw it in the news. It was shown how the matchboxes, like ours, were caught and were being emptied. Then we think: 'aah, yeah, they went there"'. According to people's perceptions, the drug users were somewhere in Bishkek, Kyrgyzstan's capital city, in Russia or elsewhere. Maintaining a distance from users allows them to differentiate themselves from consumers.

In such cases, it is clear that the legitimating narrative of hashish-making was not adopted by all in the village; it was particularly difficult for the older generation to fully approve the illegal activities of their younger family members. Thus, the signs of what criminologists and sociologists of deviance refer to as techniques of neutralization can be identified in various narratives of illegality.

\section{Cleansing tainted hashish money}

Conversely, hashish money was sometimes considered as tainted and could lead to the loss of wealth due to local beliefs in the sacred relationship between plant, nature, and man/woman. I often heard the saying "nashanyn tubu jaman" which in Kyrgyz means that hashish invites future misfortune. Consequently, it is not always described as a "good" source of income. Money earned through hashish differs from money earned raising livestock, cultivating potatoes or 
wheat, and could be considered tainted. Accidents or misfortune, such as being arrested and having to pay a large bribe, were perceived as a possible "curse" caused by hashish money. Here, we see some aspects of tainted money as similar to "polluted" money obtained through illegal gold mining in Mongolia (High, 2017); or "evil” money obtained through selling ancestral land among Kenyan tribes (1989). These concepts are derived from the local moral economy and go beyond legal aspects of how money was earned. They add an ethical layer of analysis rooted in local cultural/religious understandings of the relationship between humans and the universe.

Studies of these moral-economic principles assist us in understanding the cultural logic of bitter money and how it is perceived. Kenyan tribes use rituals to cleanse money obtained through selling ancestral land: considered as taboo (Shipton, 1989). High (2017) argues that by referring to angry spirits, which put people at constant risk of misfortune, Mongolian gold miners practiced rituals of offerings to spirits and asking Buddhist lamas to purify polluted money. At the same time, such rituals were considered insufficient and they spent much of their money on non-durable goods, including large amounts of alcohol. Shopkeepers kept buying new stock in their attempt to rid themselves of money brought by gold miners. These tactics were not a result of the self-indulgence of miners and increased greediness of shopkeepers, but a sign of how people attempted to absolve the moral restrictions of polluted money (High, 2017).

In the case of hashish production, cleansing hashish money of its bitterness was related to the everyday ethics of survival. Many respondents expressed a perception that those, who worked hard on their land and household and did not become greedy, would obtain less tainted money. In contrast, those who became greedy and lost interest in caring for their fields and livestock by turning to more profitable hashish would be dealing with tainted money and be punished in the future. Therefore, despite the fact that hashish money had some bitterness attached to it, if someone was cautious, not greedy and spent money on agriculture or on social obligations such as hosting, the money could be symbolically cleansed. Surprisingly, instead of stopping people from making hashish, through linking it to the ethics of hard work, work that supports families and enhances the community networks reinforced the overall legitimation of this illegal practice ${ }^{11}$.

\footnotetext{
${ }^{11}$ High's (2017) explanation that 'polluted money' was easily spent on non-durable goods such as drinks and food as it did not lead to future bad luck can also be seen in case of hashish money. When hashish money was used for organizing a party among young hashish-makers in summer, no symbolic cleansing was needed.
} 
Moral views about illegal practices in Toolu entered, therefore, multiple conversations with the state (or the perceived role of the state) and local beliefs based on customary understandings shaping people's perceptions of money. At first glance, the idea of "bitter" or "tainted" money is typical for traditional societies such as Toolu. Economic sociologists have commonly argued, however, that such "mental accounting" (Thaler, 1999) or considerations and classifications of income as inherently different are common in modern economies. Zelizer (1997), for example, demonstrates how modern middle-class families in the U.S. earmark their income and savings based on the source of income. These studies and my own findings show that local residents view hashish-generated income as one of the key aspects about how and why they engage in the production of hashish and how this activity is further legitimized through symbolic cleansing. In the case of a local belief system that considered hashish-making as a right, the customary belief that precautions should be taken in making hashish existed in conversation with the belief that hashish-making is work and therefore morally justified. According to respondents, it should be the state's actions that are considered unjust since these actions left rural farmers with no other source of economic support.

\section{Conclusion}

This article's primary aim was to expand upon current understandings of the complexity of the legitimation of illegal practices. Using legal pluralism as a general framework of analysis, the study analysed perspectives towards, and the questioning of state law in the context of local normative systems. By discussing how people on the ground may interpret and experience the interrelationship between state law, customary law and law based on the moral economy of hashish production, we see how this process of legitimating illegality is part of legal plurality, which subsequently invokes different layers of morality.

The article has argued that within the general framework of legal pluralism we can demarcate concepts that contribute to untangling the feelings and understandings of Toolu farmers in relation to their hashish-making. Here, the moral economy concept was crucial in identifying reasons for a low-level mirroring of state law through developing an alternative normative system. Since the 1990s, economic necessity among rural populations, alongside the 
perceived betrayal by the state combined with low-level procedural justice, has created an overarching legitimating narrative about illegal hashish-making.

Because the legitimacy of state power is based on people's belief system, the transformation in beliefs can erode trust in the state. This sheds light on the micro-dynamics of how such a system was developed based on ideas of justice and the role of state as one of the main de-legitimating sources of the power system. People in Toolu continued to make hashish and developed a moral narrative about their activity in opposition to the state's prohibition of drug production. Through reference to the moral economy it becomes possible to discuss how the majority of people felt it was morally right to make hashish in the absence of jobs and state support: hashish-making merely constituted one of their jobs. During the initial years of hashish production, the local population derived retrospective moral justification from the difficult experience of rapid economic transformations, during which people had to survive without the state welfare that had been essential to the planned economy during Soviet times.

Yet, hashish legitimation does not end with reference to economic necessity. Another crucial component of contestation of the state's legitimacy is derived from the corruption of state representatives with whom hashish-makers and middlepersons interacted on a daily basis during the harvesting period. Here, studies focussing on state representatives' actions toward the people and law were crucial in understanding the feelings of injustice and mistrust people were accumulating. The role of the state in controlling hashish harvesting was called into question as more villagers discussed their observations of injustice by state authorities and their own predatory role in hashish production and trafficking. Law enforcement officers involved in protecting sales of hashish and soliciting bribes from hashish-makers contributed to the sentiment that boundaries between what is legal and illegal have become blurred, consequently lowering the legitimacy of law as a normative system. The concept of "grey areas" merging legal and illegal practices with no clear cut separation also reminds us how, in practice, the shift from high to low mirroring of laws is not a straightforward process.

However, even within these largely accepted narratives of hashish as work and state injustice, there were cases of psychological tensions experienced throughout the community due to the reliance on the law as a guiding normative system and at the same time seeing, hearing about, or experiencing the fact that the law is broken on an everyday basis. Here, neutralization theory helps us to analyse the consequences of accepting legal systems while remaining part of 
illegality. In such cases, the response to the psychological tensions was to resort to a strategy of neutralizations.

Moreover, the local discourse on hashish-making was complicated by the cultural logic linking cannabis plants to people's destinies and the subsequent use of hashish money for various needs. We see that the local moral discourse that hashish-making is justified and right was mitigated by another belief that people should not seek to make a large personal profit from cannabis plants as this illegal practice will make their money cursed. I argue that legal pluralism as a general framework allows us to identify another normative system that is based on the spiritual understandings of people. Here, it is useful to use theories developed mainly in economic anthropology to understand the cleansing of "tainted" money. Referring to the spiritual powers of cannabis and that it can "hit" somebody back was important for people and, therefore, affected the way that the illegal hashish economy developed in the region. This belief system, "being an active and dynamic constituent of an economic life" (High, 2017: 60), was one of the reasons why people in the region did not cultivate cannabis plants and harvested hashish from wild cannabis growing in the Karkyra Valley.

Finally, the article is able to address the local points of view on law and state in a postSoviet country from a criminological perspective. I suggest that the de-legitimation of state power is due not to a nihilistic culture among the population, but is rather rooted in the political and economic processes that took place in the post-Soviet region. At the same time, the persistence of illegal drug production and other types of illegal activities in mainly emerging economies indicates that legitimation of illegality due to moral reasoning is not unique to the post-Soviet region.

\section{Bibliography}

Ahmadzai A and Kuonqui C (2011) In the shadows of the insurgency in Afghanistan: Child barering, opium debt, and the war on drugs. In: Barrett D (ed.) Children of the Drug War. New York: Idebate, 43-58. 
Beck A and Chistyakova Y (2002) Crime and policing in post-Soviet societies: Bridging the police/public divide. Policing and Society 12: 123-137.

Beckert J and Wehinger F (2012) In the shadow: Illegal markets and economic sociology. SocioEconomic Review 11(1): 5-30.

Beetham D (1991) The Legitimation of Power. London: Macmillan.

Birdsall K (2000) 'Everyday crime' at the workplace: Covert earning schemes in Russia's new commercial sector. In: Ledeneva A and Kurkchiyan M (eds) Economic Crime in Russia. Hague: Kluwer Law, 145-163.

Brooke HSG and Gans-Morse J (2016) Putin's crackdown on mortality: Rethinking legal nihilism and state capacity in light of Russia's surprising public health campaigns. Problems of PostCommunism 63(1): 1-15.

Calderón A. P (2016) Beyond Indigeneity: Coca Growing and the Emergence of a New Middle Class in Bolivia. Tucson: University of Arizona Press.

Decorte T, Potter G and Bouchard M (2011) Worldwide Weed: Global Trends in Cannabis Cultivation and Its Control. Farnham: Ashgate.

De Danieli F (2011) Counter-narcotics policies in Tajikistan and their impact on state building. Central Asian Survey 30(1): 129-145.

De Sardan J (1999) A moral economy of corruption in Africa? Journal of Modern African Studies 37(1): 25-52.

Dewey M (2012) Illegal police protection and the market for stolen vehicles in Buenos Aires. Journal of Latin American Studies 44(4): 679-702.

Engwicht N (2017) 'We are the genuine people': Legality and legitimacy in the Sierra Leonean diamond market. In: Beckert J and Dewey M (eds) The Architecture of Illegal Markets: Towards an Economic Sociology of Illegality in the Economy. Oxford: Oxford University Press, 198-217.

Galemba R (2012) 'Corn is food, not contraband': The right to 'free trade' at the MexicoGuatemala border. American Ethnologist 39(4): 716-734.

Galemba R (2013) Illegality and invisibility at margins and borders. PoLAR: Political and Legal Anthropology Review 36(2): 274-285.

Gans-Morse J (2012) Threats to property rights in Russia: From private coercion to state aggression. Post-Soviet Affairs 28(3): 263-295.

Hendley K (2015) Resisting multiple narratives of law in transition countries: Russia and beyond. Law and Social Inquiry 40(2): 531-552. 
Heyman J (1999) States and Illegal Practices. Oxford: Berg.

Heyman JM and Smart A (1999) States and illegal practices: Overview. In:

Heyman JM (ed) States and illegal practices. Oxford: Berg, pp. 1-24.

High MM (2017) Fear and Fortune: Spirit Worlds and Emerging Economies in the Mongolian Gold Rush. Ithaca, NY: Cornell University Press.

Humphrey C (2002) The Unmaking of Soviet Life: Everyday Economies after Socialism. Ithaca, NY: Cornell University Press.

Korchagina V (1987) Konoplaynyi sezon na Issyk-Kule [Cannabis season in Issyk-Kul]. Sovetskaya Kirgiriya, 6 August.

Kupatadze A (2014) Kyrgyzstan: A virtual narco-state? International Journal of Drug Policy 25(6): 1178-1185.

Kurtz-Phelan D (2005) Coca is everything here: Hard truths about Bolivia's drug war. World Policy Journal 22(3): 103-112.

Ledeneva A (2006) How Russia Really Works: The Informal Practices That Shaped Post-Soviet Politics and Business. New York: Cornell University Press.

Levin M and Satarov G (2000) Corruption and institutions in Russia. European Journal of Political Economy 16(1): 113-132.

MacCormick N (2007) Institutions of Law: An Essay in Legal Theory. Oxford: Oxford University Press.

Mackenzie S and Yates D (2016) Collectors on illicit collecting: Higher loyalties and other techniques of neutralization in the unlawful collecting of rare and precious orchids and antiquities. Theoretical Criminology 20(3): 340-357.

Mandel R and Humphrey C (2002) Markets and Moralities: Ethnographies of Postsocialism. Oxford: Berg.

Mathiesen T (1965) The Defenses of the Weak: A Sociological Study of a Norwegian Correctional Institution. London: Tavistock.

Matza D (1964) Delinquency and Drift. New York: Wiley.

Nuijten M and Anders G (eds) (2007) Corruption and the Secret of Law: A Legal Anthropological Perspective. Farnham: Ashgate. 
Paoli L, Rabkov I, Greenfield V, et al. (2007) Tajikistan: The rise of a narco-state. Journal of Drug Issues 37(4): 951-979.

Polese A (2008) If I receive it, it is a gift; if I demand it, then it is a bribe. Anthropology in Action 15(3): 47-60.

Reeves M (2014) Border Work: Spatial Lives of the State in Rural Central Asia. Ithaca, NY: Cornell University Press.

Ruggiero V and South N (1995) Eurodrugs: Drug Use, Markets and Trafficking in Europe. London: University College London Press.

Scott J (1985) Weapons of the Weak: Everyday Forms of Peasant Resistance. London: Yale University Press.

Shelley L (1995) Organized crime in the former Soviet Union. Problems of Post-Communism 42(1): $56-60$.

Shipton P (1989) Bitter Money: Cultural Economy and Some African Meanings of Forbidden Commodities. Washington, DC: American Ethnological Society Monograph Series.

Slade G and Kupatadze A (2017) Popular punitiveness? Punishment and attitudes to law in postSoviet Georgia. Europe-Asia Studies 69(6): 879-896.

Steinberg M, Hobbs J and Mathewson K (2004) Dangerous Harvest: Drug Plants and the Transformation of Indigenous Landscapes. Oxford: Oxford University Press.

Stephenson S (2015) Gangs of Russia: From the Streets to the Corridors of Power. Ithaca/London: Cornell University Press.

Sykes G and Matza D (1957) Techniques of neutralization: A theory of delinquency. American Sociological Review 22: 664-670.

Tamanaha B (2001) A General Jurisprudence of Law and Society. Oxford: Oxford University Press.

Thaler RH (1999) Mental accounting matters. Journal of Behavioral Decision Making 12(3): 183-206.

Thompson E (1991) Customs in Common. New York: The New Press.

Thompson E (1971) The moral economy of the English crowd in the eighteenth century. Past and Present 50(1): 76-136.

Tyler T (2004) Enhancing police legitimacy. Annals of the American Academy of Political and Social Science 593(1): 84-99.

Urinboyev R and Svensson M (2013) Living law, legal pluralism, and corruption in post-Soviet Uzbekistan. Journal of Legal Pluralism and Unofficial Law 45(3): 372-390. 
Watt P and Zepeda R (2012) Drug War Mexico: Politics, Neoliberalism and Violence in the New Narcoeconomy. London: Zed.

Webb J, Tihanyi L, Ireland R, et al. (2009) You say illegal, I say legitimate: Entrepreneurship in the informal economy. Academy of Management Review 34(3): 492-510.

Werner C (2000) Gifts, bribes, and development in post-Soviet Kazakstan. Human Organization 59(1): 11-22.

Westermeyer J (2004) Opium and the people of Laos. In: Steinberg M, Hobbs J and Mathewson K (eds) Dangerous Harvest: Drug Plants and the Transformation of Indigenous Landscapes. Oxford: Oxford University Press, 115-132.

Zelizer VA (1997) The Social Meaning of Money. Princeton, NJ: Princeton University Press. 